\title{
Perspective on Photovoltaic Amorphous Silicon
}

W. Luft

B. Stafford

B. von Roedern

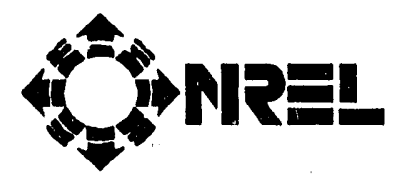

National Renewable Energy Laboratory (formerly the Solar Energy Research Institute) 1617 Cole Boulevard Golden, Colorado 80401-3393

A Division of Midwest Research Institute Operated for the U.S. Department of Energy under Contract No. DE-AC02-83CH10093 
On September 16, 1991 the Solar Energy Institute was designated a national laboratory, and its name was changed to the Natlonal Renewable Energy Laboratory.

\section{NOTICE}

This repoit was prepared as an account of work sponsored by an agency of the United States government. Neither the United States government nor any agency thereof, nor any of their employees, makes any warranty, express or implied, or assumes a.ny legal liability or responsibility for the accuracy, completeness, or usefulness of any information, apparatus, product, or process disclosed, or represents that its use would not infringe privately owned rights. Reference herein to any specific commercial product, process, or service by trade name, trademark, manufacturer, or otherwise does not necessarily constitute or imply its endorsement, recommendation, or favoring by the United States government or any agency thereof. The views and opinions of authors expressed herein do not necessarily state or reflect those of the United States government or any agency thereot.

\section{Printed in the United States of America \\ Available from:}

National Technical Information Service

U.S. Department of Commerce

5285 Port Foyal Road

Springfield, VA 22161

Price: Microfiche A01

Printed Cupy AO3

Codes are used for pricing all publications. The code is determined by the number of pages in the publication. Information pertaining to the pricing codes can be found in the current issue of the following publications which are generally available in most libraries: Energy Research Abstracts (ERA); Government Reports Announcements and Index (GRA and I); Scientific and Technical Abstract Reports (STAR); and publication NTIS.PR-360 available from NTIS at the above address. 


\title{
PERSPECTIVE ON PHOTOVOLTAIC AMORPHOUS SILICON
}

\author{
W. Luft, B. Stafford, and B. von Roedern \\ National Renewable Energy Laboratory \\ 1617 Cole Boulevard, Golden, CO 80401, USA
}

\begin{abstract}
Amorphous silicon is a thin film option that has the potential for a cost-effective product for large-scale utility photovoltaics application. The initial efficiencies for single-junction and multijunction amorphous silicon cells and modules have increased significantly over the past 10 years. The emphasis of research and development has changed to stabilized efficiency, especially that of multijunction modules. NREL has measured 6.3\%-7.2\% stabilized amorphous silicon module efficiencies for U.S. products, and $8.1 \%$ stable efficiencies have been reported by Fuji Electric. This represents a significant increase over the stabilized efficiencies of modules manufactured only a few years ago. An increasing portion of the amorphous silicon U.S. government funding is now for manufacturing technology development to reduce cost. The funding for amorphous silicon for photovoltaics by Japan over the last 5 years has been about $50 \%$ greater than that in the United States, and by Germany in the last 2-3 years more than twice that of the U. S. Amorphous silicon is the only thin-film technology that is selling large-area commercial modules. The cost for amorphous silicon modules is now in the $\$ 4.50$ range; it is a strong function of plant production capacity and is expected to be reduced to $\$ 1.00-1.50 / \mathrm{W}_{\mathrm{p}}$ for plants with $10 \mathrm{MW} / \mathrm{year}$ capacities.
\end{abstract}

\section{Introduction}

Research on amorphous silicon for photovoltaics has been funded by the United States Department of Energy (U.S. DOE) since the late 1970s. This paper examines how much has been spent and what that funding has accomplished in the United States. The government funding for amorphous silicon has not only helped establish a photovoltaics industry in the United States, but has also helped to establish technologies such as amorphous silicon thin-film transistors and optical sensors. The funding has also helped other thin-film photovoltaics in areas of encapsulation for environmental protection. At the present time, an increasing portion of the amorphous silicon funding is directed to improve the U.S. manufacturing technology to reduce costs. A much larger portion of the overall investment in amorphous silicon in the United States than the government funding has come from private investors. The present emphasis of the development in the U.S. is for large power modules for the utility market rather than for consumer products.

\section{History}

In the 1970s, the U.S. Department of Energy began to support research and development in amorphous silicon for photovoltaics, and a few private U.S. firms, such as Energy Conversion Devices and RCA, began develcping the technology. In 1974, the first laboratory-size amorphous 
silicon solar cell was produced with an efficiency of $2 \%$. The first patent on an amorphous silicon solar cell was issued to RCA in 1977. The government's total expenditure through 1979 for a-Si was approxinately $\$ 5$ million, and RCA's total spending was comparable. The government/RCA partnership continued until mid-1982. A pivotal point in the amorphous silicon technology was achieved in 1982 with RCA's announcement of the first 10\%-efficient amorphous silicon solar cell [Catalano et al. 1982]. In 1982, Solarex Corporation, a subsidiary of Amoco Corporation, purchased RCA's technology, and by 1983, Solarex and the U.S. government had formed a new partnership to continue the amorphous silicon research [Sabisky and Annan, 1988]

In 1983, DOE's Photovoltaic Energy Technology Division began plans to establish the Amorphous Silicon Research Project at the Solar Energy Research Institute. The project was intended to establish a cooperative research venture with teams of researchers at universities and national laboratories supporting a collaborative government/industry program [Sabisky and Annan, 1988]. In FY 1984, a series of projects - cost-shared by DOE with U.S. industry - began under the Amorphous Silicon Research Project. Ultimately, there were three sets of these projects, each set lasting for a nominally three-year period. The objectives of these projects were for the first set to improve the efficiency for single-junction cells, for the second set to improve multi-junction cells, and for the third set to improve the stabilized performance of multijunction modules. The organizations that were funded were the following:

\begin{tabular}{|c|c|c|}
\hline FY 84/87 & FY 87/90 & FY $90 / 93$ \\
\hline Solarex & Solarex & Solarex \\
\hline Chronar & Chronar & $\begin{array}{l}\text { United Solar Systems } \\
\text { Corp. }\end{array}$ \\
\hline Spire & Arco Solar & $\begin{array}{l}\text { Advanced Photovoltaic } \\
\text { Systems, Inc. }\end{array}$ \\
\hline $3 \mathrm{M}$ & Energy Conversion Devices & Glasstech Solar, Inc. \\
\hline
\end{tabular}

In 1984, several companies in the United States and Japan introduced the first amorphous silicon power modules of at least one square foot in area with power ratings of at least $5 \mathrm{~W}$. In 1985, amorphous silicon consumer products constituted $32 \%$ of the total photovoltaic world market. In 1986, several companies introduced 30-40 W power modules.

In 1986, the utility sector began joint projects with U.S. photovoltaic manufacturing companies to begin testing thin-film amorphous silicon systems. A $100-\mathrm{kW}_{\mathrm{p}}$ array developed by Chronar and deployed by the Alabama Power Company has been operating since June 1986. In August 1986, the Philadelphia Electric Company and Solarex started a 3.6-kW $\mathrm{k}_{\mathrm{p}}$ amorphous silicon test system. Photovoltaics for Utility-Scale Applications (PVUSA), a cooperative project between the U.S. Department of Energy, the California Energy Commission, the Electric Power Research Institute, and eleven utilities and government entities, started testing amorphous silicon modules in mid-1989 with three nominally $20-\mathrm{kW}$ systems.

From 1978 to 1985, the initial (non-stabilized) efficiency of small-area, single-junction amorphous silicon devices (less than $1-\mathrm{cm}^{2}$ area) increased by about 1.2 percentage points per year to the current level of approximately $12 \%$. Improvements in the performance of monolithic amorphous silicon single-junction modules (about $1,000 \mathrm{~cm}^{2}$ area) have paralleled the improvements in small-area cell efficiencies and in 1989 were at the level of $10 \%$ (nonstabilized). Initial efficiencies for $3,000-5,000 \mathrm{~cm}^{2}$ monolithic amorphous silicon single-junction 
modules were 6\%-8\% in 1989 [Luft and Stafford, 1990].

A transition in emphasis in the U. S. amorphous silicon program did occur in FY 1990 from single-junction amorphous silicon cell and module research to multijunction module research, and from initial efficiency to stabilized efficiency. NREL implemented the transition in FY 1991 to focus industrial subcontractors and university subcontractors on maximizing stabilized efficiencies, rather than to focus on maximizing initial performance and minimizing degradation.

Table 1 summarizes the progress made in amorphous silicon cells and modules from 1983 through 1989. Single-junction module initial efficiencies increased from $4 \%$ to $9.8 \%$, and multijunction module initial efficiencies went from nothing to $8.4 \%$. Single-junction module sizes increased from $412 \mathrm{~cm}^{2}$ to $1.2 \mathrm{~m}^{2}$. Worldwide amorphous silicon shipments increased from 3.1 to $13.1 \mathrm{MW}$.

Table 1. 1983-1989 Progress in Photovoltaic (PV) Amorphous Silicon Technology. (Initial, Non-Stabilized Performance) [Luft and Stafford, 1990]

\begin{tabular}{llll}
\hline & 1983 & 1987 & 1989 \\
\hline & & & \\
Single-junction cell efficiency for $0.25 \mathrm{~cm}^{2}$ & $10 \%$ & $11.7 \% *$ & $11.9 \%^{*}$ \\
Best short-circuit current density $\left(\mathrm{mA} / \mathrm{cm}^{2}\right)$ & 16 & 19 & 19 \\
Single-junction module efficiency for $800-933 \mathrm{~cm}^{2}$ & $4 \%$ & $7.9 \% *$ & $9.8 \%^{*}$ \\
Maximum single-junction module size & $412 \mathrm{~cm}^{2}$ & $2800 \mathrm{~cm}^{2}$ & $1.2 \mathrm{~m}^{2}$ \\
Typical light-induced degradation for single- & $\mathrm{NA}$ & $30-50 \%$ & $30 \%$ \\
junction modules & & & \\
Multijunction cell efficiency for $0.25 \mathrm{~cm}^{2}$ & $8.6 \%$ & $11 \%$ & $13.3 \% *$ \\
$\begin{array}{l}\text { Multijunction module efficiency for } 800 \mathrm{~cm}^{2} \\
\text { Maximum multijunction module size }\end{array}$ & None & $\sim 5 \%$ & $8.4 \% *$ \\
Typical light-induced degradation for multijunction & $\mathrm{None}$ & $\mathrm{None}$ & $800 \mathrm{~cm}^{2}$ \\
modules & & $\mathrm{NA}$ & $10 \%-20 \%$ \\
Amorphous silicon worldwide PV shipments & $3.1 \mathrm{MW}$ & $10.3 \mathrm{MW}$ & $13.1 \mathrm{MW}$ \\
Amorphous silicon world PV market share & $15 \%$ & $37 \%$ & $31 \%$ \\
United States share of the world a-Si market & 0 & $16 \%$ & $17 \%$ \\
\end{tabular}

*NREL verified, $\mathrm{NA}=$ not available.

\section{April 1992 Status}

Recause of the high light-induced degradation for single-junction amorphous silicon devices, NREL ilow direct its research to multijunction devices. Because our goal is the power market, the preponderance of development is on large-area devices (modules) rather than on small-area cells. Real-timt light-soaking tests at NREL have only been done on modules, not on cells. Improved stabilized efficiencies for amorphous silicon modules were measured by NREL: $7.2 \%$ efficiency for a Solarex triple-junction prototype module $\left(962 \mathrm{~cm}^{2}\right.$ aperture area), and $6.3 \%$ efficiency for a United Solar Systems Corporation dual-junction module from their production 
line $\left(3,676 \mathrm{~cm}^{2}\right.$ aperture area). These stabilized efficiencies of $6 \%-7 \%$ for commercial and prototype modules are a significant improvement from the 3\%-5\% stable efficiencies of such modules produced three or four years ago. The state-of-the-art efficiencies for U.S. amorphous silicon products are shown in Table 2.

U.S. industry produces amorphous silicon modules for the commercial power market in sizes that range from $1 \mathrm{ft}^{2}$ to $1.2 \mathrm{~m}^{2}$. Amorphous silicon modules have passed the PVUSA qualification tests that are based on the NREL interim qualification tests and procedures for terrestrial photovoltaic thin-film, flat-plate modules. Advanced Photovoltaic Systems, Inc. has been selling a $400-\mathrm{kW}$ amorphous silicon system to PVUSA (US-1 system) for a total system price of $\$ 5 / \mathrm{W}$. The cost to PVUSA for the foundation and support structure was $\$ 30 / \mathrm{m}^{2}$, considerable less than for previous support structures [Candelario et al., 1991]. The price for the 1.2- $\mathrm{m}^{2}$-sized amorphous silicon modules alone was about $\$ 2.50 / \mathrm{W}$. The U.S. amorphous silicon production capacity in early 1992 was $5 \mathrm{MW} /$ year. The capacity is expected to be over $20 \mathrm{MW} / \mathrm{year}$ by 1994.

Table 2. NREL-Confirmed State-of-the-Art Efficiencies for Amorphous Silicon Cells and Modules in the United States. (Values are total-area efficiencies for cells, unless otherwise indicated, and aperture-area efficiencies for modules.

\begin{tabular}{lll}
\hline & Initial & Stabilized \\
\hline Single-Junction Technology & $11.9 \%$ & \\
Small-area cells & $9.8 \%$ & \\
Modules $\left(933 \mathrm{~cm}^{2}\right)$ & $7.8 \% *$ & \\
Module $\left(4,700 \mathrm{~cm}^{2}\right)$ & $6.2 \%$ & $4.7 \% *$ \\
Modules $\left(1.2 \mathrm{~m}^{2}\right)$ & $15 \%-30 \%$ & \\
Light-induced degradation & & \\
Multijunction Technology & $13.3 \% \dagger$ & \\
Small-area triple-junction cells & $12.4 \% \dagger$ & $9.7 \%(10.4 \% \dagger)$ \\
Small-area dual-junction cells $(\mathrm{Si} / \mathrm{SiGe})$ & $11.9 \% * \dagger$ & \\
Small-area dual-junction cells $(\mathrm{Si} / \mathrm{Si})$ & $8.2 \%$ & \\
Dual-Junction modules $\left(1,100 \mathrm{~cm}^{2}\right)$ & $7.4 \%$ & $6.3 \%$ \\
Dual-Junction modules $\left(3,676 \mathrm{~cm}^{2}\right)$ & $9.0 \%$ & $7.2 \%$ \\
Triple-junction modules $\left(940 \mathrm{~cm}^{2}\right)$ & $9.7 \%$ & \\
Triple-junction modules $\left(795 \mathrm{~cm}^{2}\right)$ & & \\
\hline
\end{tabular}

*not confirmed by NREL; †active-area efficiency.

In 1991, worldwide amorphous silicon photovoltaics shipments were $13.7 \mathrm{MW}, 25 \%$ of all photovoltaic shipments (55.3 MW). Out of the 13.7 MW of amorphous silicon shipped in 1991, 8.3 MW were for indoor consumer goods and 5.4 MW were for outdoor applications. The U.S. amorphous silicon shipments were $1 \mathrm{MW}$ or $7 \%$ of the amorphous silicon world market. The U.S. shipments in 1991 were low compared to the 2.1 MW shipped in 1990, because the United Solar Systems Corporation only restarted production late in 1991 and Advanced Photovoltaic Systems, Inc. only started selling Eureka modules in November 1991. The Japanese amorphous silicon shipments in 1991 were $10.4 \mathrm{MW}$, about the same as in 1990 [Maycock 1992]. 


\section{International Amorphous Silicon Photovoltaics Status}

The Japanese Sunshine project for amorphous silicon has the following efficiency goals for 1992: $13 \%$ for small-area cells, $12 \%$ for $100-\mathrm{cm}^{2}$ areas with $<10 \%$ degradation in one year, $10 \%$ for $1,200-\mathrm{cm}^{2}$ areas with $<15 \%$ degradation in one year, $14 \%$ for $100-\mathrm{cm}^{2}$ a-Si/polycrystalline silicon, and $13 \%$ for $1,200-\mathrm{cm}^{2}$ a-Si/compound tandem devices. The objective of the Japanese 1989-1992 research program is to advance the fundamental technology base for amorphous silicon in support of demonstrating low-cost $(\$ 1.00-\$ 1.50 / \mathrm{W})$ mass production in large-scale $(100 \mathrm{MW} / \mathrm{yr})$ manufacturing plants by 1995 . The designs and technologies being considered are single-junction and multijunction amorphous silicon devices and amorphous silicon on polycrystalline silicon ( $<50 \mu \mathrm{m}$ thick) or polycrystalline thin films. The research will focus on mechanisms limiting stability, methods to improve reliability, high-quality low-band-gap alloy development, module design technology, and production process research. A proposed new initiative for a $5 \%$ budget increase is a $20 \%$-efficient amorphous silicon cell with $5 \%$ degradation by the year 2000 .

Fifteen Japanese organizations have reported $>10 \%$ initial efficiencies for amorphous silicon cells. Osaka University claims to have achieved $13.29 \%$ efficiency for an a-Si/polycrystalline Si tandem cell with an area of $0.30 \mathrm{~cm}^{2}, 13.3 \%$ for an a-Si/CdS-CdTe cell with an area of $1 \mathrm{~cm}^{2}$, and $14.8 \%$ for an a-Si/crystalline $\mathrm{Si}$ cell with an area of $0.065 \mathrm{~cm}^{2}$. For single-junction amorphous silicon modules, Sanyo claims a $10.2 \%$ initial total-area efficiency for a $100-\mathrm{cm}^{2}$ module, and Fuji claims an $8.7 \%$ initial efficiency for a $1,200-\mathrm{cm}^{2}$ module. For multijunction amorphous silicon modules, Mitsubishi claims $10.6 \%$ initial efficiency for a $100-\mathrm{cm}^{2}$ module. Fuji claims a $10 \%$ stable efficiency (11.4\% initial) for a $1-\mathrm{cm}^{2}$ dual-junction cell, an $8.1 \%$ 1000-hour stabilized (9.9\% initial, $8.5 \%$ after 500 hours) total-area efficiency for a $1,200-\mathrm{cm}^{2}$ dual-junction a-Si/a-Si module, and an $8.5 \%$ initial efficiency for a $4,800-\mathrm{cm}^{2}$ module.

The goal for the Commission of European Communities amorphous silicon photovoltaics program is the development of modules with an $8 \%$ initial conversion efficiency at a cost of $\$ 1.2 / \mathrm{W}_{\mathrm{p}}$ under a multinational partnership (called OASIS) involving six academic laboratories and an industrial laboratory in France. In addition, there are national programs in amorphous silicon in France, Germany, Italy, and Spain. Under the French program, SOLEMS/CFP plans to eventually achieve $9 \%$ stabilized efficiencies for $5,000-\mathrm{cm}^{2}$ modules in a facility with 1 MW/yerir-shift capacity. The Italian program has research at the ENEA photovoltaic research center at Portici mostly devoted to amorphous silicon. The center works in cooperation with the Universities of Rome, Bari, Naples, Turin, and Messina. So far, $8 \%$ initial efficiency $1-\mathrm{cm}^{2}$ single-junction cells have been achieved by glow discharge deposition. Siemens in Germany is expanding their amorphous silicon production capacity to $5 \mathrm{MW} /$ year [Luft et al., 1992], and Phototronics has inaugurated a $1 \mathrm{MW} /$ year plant in October 1991.

\section{U. S. Project Goals}

The near-term objective of the Amorphous Silicon Research Project is to achieve a $12 \%$ stable prototype module efficiency and a 10\% commercial module efficiency by 1994 in accordance with the goals in DOE's Five Year Research Plan (FY 1991-FY 1995). This will be achieved through improvements in the optoelectronic properties of amorphous-silicon-based alloy materials. 
Additional near-term objectives are to gain an understanding of the metastability in amorphous silicon, to reduce the costs to $\$ 1 / \mathrm{Wp}$, and to foster a viable amorphous silicon photovoltaic industry in the United States.

Long-term objectives (year 2005) are to achieve commercial amorphous silicon module stable efficiencies of greater than $12 \%$, eliminate the Staebler-Wronski effect, and reduce module costs for electric power utility applications to $\$ 0.50 / \mathrm{W}_{\mathrm{p}}$ (corresponding to 6 cents $/ \mathrm{kWh}$ ).

The decrease in production cost can be achieved by increasing plant capacity. The present plant volume is around $2 \times 10^{4} \mathrm{~m}^{2} /$ year and the cost at a $6 \%$ stable efficiency is $\$ 4.00-4.50 / \mathrm{W}$ peak. At a capacity of 10 MW/year or $1.3 \times 10^{5} \mathrm{~m}^{2} /$ year, the cost is reduced to the $\$ 1.00-1.50 / \mathrm{W}$ range (see Figure 1). It is this great cost reduction with increasing plant volume that makes amorphous silicon so attractive. To put the amorphous silicon costs into perspective, the costs for single-crystal silicon, multicrystalline silicon, ribbon silicon, and advanced highefficiency silicon modules at a $10-\mathrm{MW}$ per year production level range from $\$ 2.42$ to $\$ 3.07 / \mathrm{W}_{\mathrm{p}}$ [Hogan et al., 1991]. The cost projections for other thin-film technologies, such as copperindiumdiselenide and cadmium telluride, are similar to those for amorphous silicon but these technologies do not have the extensive production experience as has amorphous silicon to base the cost estimates

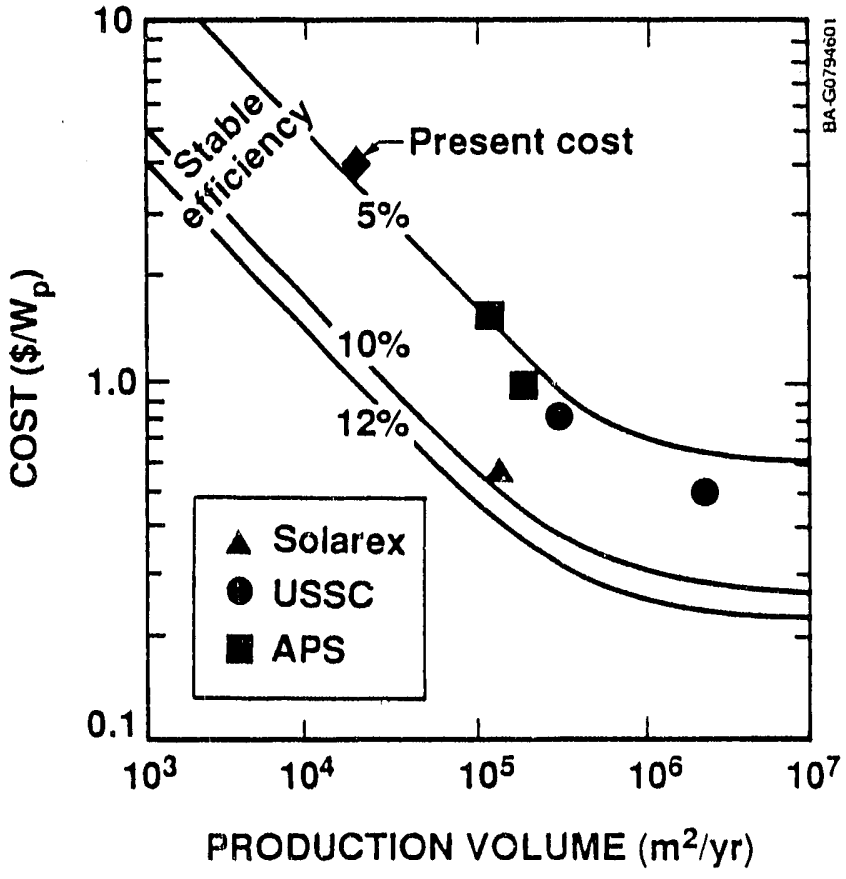

Figure 1. Cost projection for amorphous silicon modules as a function of plant production volume and efficiency. on [Kapur and Basol, 1991].

The goal of increased stable module efficiency is supported by the third set of amorphous silicon research projects cost-shared between the U.S. government and industry. Cost reductions through improved module manufacturing processes, improved product quality, increased plant capacity, as well as through increased production efficiency will be supported by the Photovoltaic Manufacturing Technology initiative. We expect to achieve a cost of approximately $\$ 1 / \mathrm{Wp}$ by FY 1995 as a result of the Manufacturing Technology initiative.

\section{Funding}

The U.S. DOE funding of amorphous silicon for photovoltaics from fiscal year (FY) 1978 through FY 1992 at the National Renewable Energy Laboratory (NREL) (formerly the Solar Energy Research Institute), the Jet Propulsion Laboratory, and the Radio Corporation of America (RCA) was roughly $\$ 110$ million, which is about $10 \%$ of the total photovoltaics U.S. government budget since its inception. Part of this funding was for an amorphous silicon research project by industrial companies cost-shared between the government and industry. This cost-shared 
project represents about $\$ 30$ million out of the $\$ 110$ million of DOE's amorphous silicon funding through FY 1992, with the industry cost share being \$24 million. A much larger investment than that made by the U.S. government was made by private investors in the U.S. The government funding in recent years for amorphous silicon, and the total government photovoltaic budget in three countries, are shown in Table 3. The amorphous silicon program funded by the Commission of European Communities amounts to about $\$ 2.4$ million per year. The funding for amorphous silicon in the United States since 1988 has been $\$ 10$ million on an average from FY 1988 through FY 1992. The funding for that period by Japan has been about $50 \%$ greater than that in the U.S., but has been declining. It must be remembered that salaries for university researchers in Japan do not come out of its photovoltaic budget. In the last 2-3 years the amorphous silicon government funding in Germany has been more than twice that in the U.S., however, an increasing fraction of their thin-film budget may be going to other technologies than amorphous silicon. The German government funding to industry is cost shared by industry by at least 50\%. The higher funding for amorphous silicon in Japan and Germany may eventually lead to a shift of research leadership as already exemplified by the stable efficiencies achieved by Fuji Electric in Japan.

Since 1991, an increasing share of the amorphous silicon government budget has been for improvement in the manufacturing technology. The share for manufacturing technology and product development is now nearly $50 \%$ of the amorphous silicon budget and is expected to become an even greater share in future years.

Table 3. Government Funding for Amorphous Silicon and the Total Photovoltaic (PV) Budget in the United States, Japan, and Germany over Several Years. (In millions of U.S. Dollars) [Rauber and Wollin, 1992; Goto, 1992; Maycock, 1992].

\begin{tabular}{lllllll}
\hline Year & \multicolumn{3}{l}{$\begin{array}{l}\text { Amorphous Silicon } \\
\text { PV Funding }\end{array}$} & \multicolumn{3}{l}{ Total PV Budget } \\
& U.S. & Japan $^{\text {a) }}$ & Germany $^{\text {b) }}$ & U.S. & Japan & Germany \\
\hline FY 1988 & 9.5 & 22.3 & NA & 34.7 & 53.1 & 44 \\
FY 1989 & 10.7 & NA & 15.3 & 35.1 & NA & 51 \\
FY 1990 & 7.1 & 15.7 & 23.4 & 34.3 & 53.3 & 59 \\
FY 1991 & 12.0 & 14.5 & 27.6 & 46.1 & 53.5 & 67 \\
FY 1992 & 10.8 & 13.1 & NA & 60.4 & $60.5^{\mathrm{c})}$ & 100 \\
\hline
\end{tabular}

a) Does not include university research salaries.

b) Thin-film funding, mainly for amorphous silicon.

c) Includes $\$ 9.7 \mathrm{M}$ for public and overseas installations. 


\section{Conclusions}

The initial efficiencies for single-junction and multijunction amorphous silicon cells and modules have increased significantly over the past 10 years, but cell efficiencies have reached a plateau in the range of $11 \%-13 \%$ since 1989 . The emphasis of research and development has changed to stabilized efficiency, especially that of multijunction modules. NREL has measured $6.3 \%-7.2 \%$ stabilized module efficiencies for U.S. products, and $8.1 \%$ efficiencies have been reported by Fuji Electric. Japan and Germany have had significantly higher budgets for amorphous silicon than the United States over the past 4-5 years which may eventually give them a technology lead. The cost for amorphous silicon modules is now in the $\$ 4.50$ range (even lower for very large modules and large production runs); it is a strong function of plant production capacity and is expected to be reduced to $\$ 1.00-1.50 / \mathrm{Wp}$ for plants with $10 \mathrm{MW} /$ year capacities. To reach the cost goals, an increasing fraction of the U.S. government funding is devoted to improving the amorphous silicon manufacturing technology.

\section{References}

Candelario, T. R., S. L. Hester, T. U. Townsend, D. J. Shipman, "PVUSA - Performance, Experience, and Cost", Conference Record of the 22 nd IEEE Photovoltaic Specialists Conference, New York: Institute of Electrical and Electronic Engineers, 1991, pp. 493-500.

Catalano, A., R. V. D'Aiello, J. Dresner, B. F. Faughnan, A. Firester, J. Kane, H. Schade, Z. E. Smith, G. Swartz, and A. Triano, Conference Record of the 16th IEEE Photovoltaic Specialists Conference, New York: Institute of Electrical and Electronic Engineers, 1982, p. 1421

Goto, T., "Photovoltaic R\&D Programme in Japan (Sunshine Project)", 6th International Photovoltaic Science and Engineering Conference, New Delhi: Oxford \& IBH Publishing Co. Pvt. Ltd., 1992, pp. 521-527.

Hogan, S., G. Darkazalli, and R. Little, "10 MW per year Solar Module Production Manufacturing Cost Analysis", Proceedings 1991 Solar World Congress, (Biennial Congress of the International Solar Energy Society), Oxford: Pergamon Press, Vol. 1, Part 1, 1991, pp. 41-45.

Kapur, V. K., and B. M. Basol, "Status of Polycrystalline Solar Cell Technology", 22nd IEEE Conference Record of the 22nd IEEE Photovoltaic Specialists Conference, New York: Institute of Electrical and Electronic Engineers, 1991, pp. 23-28.

Luft, W., and B. Stafford, Amorphous Silicon Research Project Government/Industry Program: Review and Assessment, SERI/TP-211-3933, Golden, Colorado: Solar Energy Research Institute, Sept. 1990, NTIS Accession No. DE90000376,.

Luft, W., B. Stafford, B. von Roedern, and R. DeBlasio, "Prospects for Amorphous Silicon Photovoltaics", to be published in Solar Energy Materials and Solar Cells, 1992.

Maycock, P., private communication, January 1992 and Photovoltaic News, February and March 1992. 
Rauber, A., and K. Wollin, "Photovoltaic R\&D in the Federal Republic of Germany", 6th International Photovoltaic Science and Engineering Conference, New Deihi: Oxford \& IBH Publishing Co. Pvt. Ltd., 1992, pp. 529-532.

Sabisky, E. S., and R. A. Annan, Amorphous Silicon: A Government/Industry Success Story, Golden, Colorado: Solar Energy Research Institute, SERI/TP-211-2572, 1988. Also in PV International February 1988. 

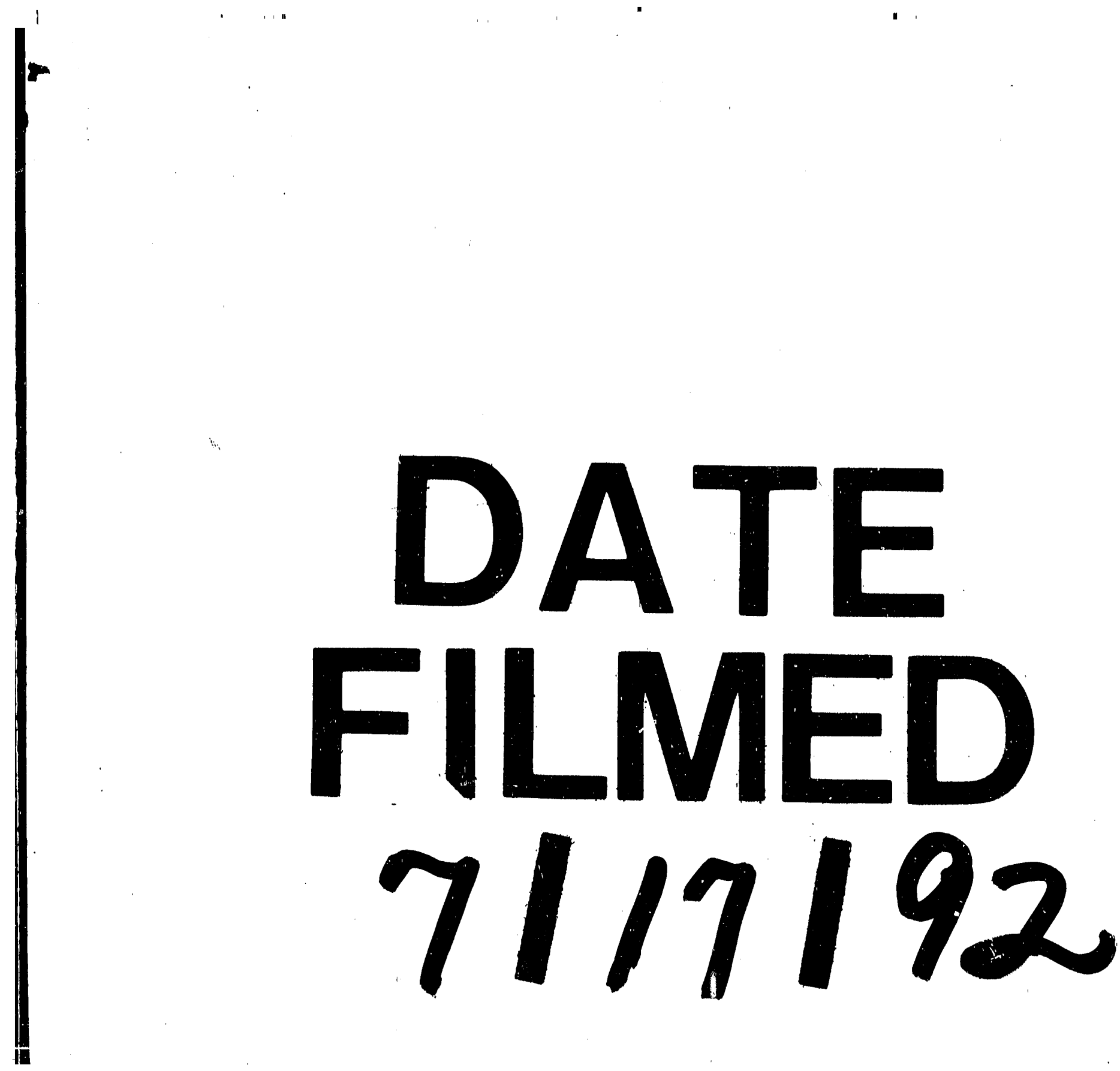